Glosy Studia luridica Lublinensia 21, 2014

Magdalena Budyn-Kulik

\title{
Wyrok Sądu Apelacyjnego w Białymstoku z dnia 21 maja 2013 r., II AKa 88/13, LEX nr 1353600
} aneza: Uświadomienie możliwości spowodowania śmierci nie przesądza
ani rodzaju zamiaru, ani nawet samej umyślności.

Dwaj sprawcy - K. Ł. i D. P. - zostali oskarżeni o to, że w dniu 23 grudnia 2011 r., działając wspólnie i w porozumieniu, ze szczególnym okrucieństwem, z przyczyn zasługujących na szczególne potępienie, chcąc pozbawić życia J. Ż., zadali mu co najmniej kilkanaście uderzeń kuchenną szafką w głowę, uderzali go pięściami w okolice głowy, przytrzymywali i dusili pokrzywdzonego, kopali po całym ciele. W wyniku tego J. Ż. doznał obrażeń ciała, co doprowadziło do urazu czaszkowo-mózgowego i w rezultacie ostrej niewydolności krążenia i oddychania, a następnie śmierci. Po zakończeniu działania K. Ł. zdjął J. Ż. spodnie i bieliznę i w odbyt (celem poniżenia) włożył kij od szczotki. Sąd Okręgowy w O. wyrokiem z dnia 5 lutego 2013 r., II K 46/12, uznał oskarżonych za winnych tego, że w dniu 23 grudnia 2011 r., działając wspólnie i w porozumieniu, wzięli udział w pobiciu J. Ż., zadając mu szereg uderzeń i ciosów po całym ciele, czym spowodowali szereg obrażeń, które doprowadziły do urazu czaszkowo-mózgowego i w rezultacie ostrej niewydolności krążenia i oddychania, a następnie śmierci J. Ż. Czyn ten został zakwalifikowany jako przestępstwo z art. 158 § 3 k.k. W zw. z $§ 1$. Oskarżonemu K. Ł. sąd wymierzył karę 7 lat pozbawienia wolności, zaś oskarżonemu D. P. karę 3 lat i 6 miesięcy pozbawienia wolności oraz zasądził od oskarżonych na rzecz pokrzywdzonego P. Ż. kwoty po 20000 złotych tytułem nawiązki.

Od tego wyroku wnieśli apelację obrońcy oskarżonych oraz prokurator. Dotyczyła ona wymiaru kary. Obrońca K. Ł. wniósł o złagodzenie wymierzonej kary pozbawienia wolności i obniżenie zasądzonej nawiązki do 10000 złotych, zaś obrońca D. P. o złagodzenie wobec tego oskarżonego kary do 2 lat pozbawienia wolności.

Prokurator podniósł zarzut obrazy przepisów postępowania, co miało wpływ na treść wyroku (art. 7 i 410 k.p.k.) poprzez dokonanie dowolnej, a nie swobod- 
nej oceny materiału dowodowego, oraz przez przekonanie sądu co do przebiegu zdarzenia jedynie na podstawie dowodów korzystnych dla oskarżonych. Część zarzutów dotyczyła ustaleń faktycznych.

Prokurator odniósł się krytycznie do przyjęcia przez sąd wersji, że oskarżonym nie można przypisać nawet ewentualnego zamiaru dążenia do śmierci pokrzywdzonego, ponieważ uderzając pokrzywdzonego, liczyli, że spowodują jedynie obrażenia ciała, a nie śmierć. Jednak lokalizacja ciosów w obrębie głowy, sposób działania oskarżonych i stwierdzona przez sąd motywacja - zdaniem prokuratora - wskazują na to, że oskarżeni działali z bezpośrednim zamiarem zabójstwa. Prokurator zarzucił sądowi I instancji także obrazę przepisów postępowania, mającą wpływ na treść wyroku (art. $424 \S 1$ k.p.k.), co polegało na lakonicznym i pobieżnym uzasadnieniu orzeczenia zarówno w zakresie opisu stanu faktycznego, jak i omówienia dowodów. Wniósł też o uchylenie zaskarżonego wyroku i przekazanie sprawy Sądowi Okręgowemu w Ostrołęce do ponownego rozpoznania.

Sąd Apelacyjny w Białymstoku w II Wydziale Karnym, po rozpoznaniu w dniu 21 maja 2013 r. sprawy, zmienił zaskarżony wyrok w ten sposób, że uchylił rozstrzygnięcie o nawiązce orzeczonej na podstawie art. $46 \S 2$ k.k., zaś w pozostałej części zaskarżony wyrok utrzymał w mocy.

Choć nie jest to przedmiotem niniejszej glosy, warto zwrócić uwagę na fragment uzasadnienia sądu apelacyjnego. Odnosząc się do zarzutu niedostatecznego uzasadnienia rozstrzygnięcia sądu I instancji zawartego w apelacji prokuratora, stwierdzono, że wskazane przez sąd motywy wyroku były nadmiernie lakoniczne. Sąd apelacyjny podkreślił, że uzasadnienie wyroku, zwłaszcza w tak trudnej materii dotyczącej pogranicza zabójstwa i pobicia, powinno być czytelne, ,albowiem sąd nie sobie, a stronom musi wykazać powody swojej decyzji. Niepoświęcenie dostatecznej uwagi pisemnym motywom jest też przejawem nonszalancji, która nie buduje autorytetu sądu [...]".

Jest to niezwykle ważkie stwierdzenie. Uzasadnienie sporządzone przez sąd nie tylko stanowi podstawę do sprawdzenia poprawności przeprowadzonego postępowania, rozumowania i wniosków wyciągniętych przez sąd I instancji, ale służy także wypełnianiu przez prawo karne i proces karny ich funkcji. Jedną $\mathrm{z}$ nich jest budowanie świadomości prawnej nie tylko osób bezpośrednio zainteresowanych rozstrzygnięciem w konkretnej sprawie, ale również całego społeczeństwa. Prawo karne pełni również funkcję sprawiedliwościową. Większość ludzi nie zdaje sobie sprawy z pewnych ograniczeń w przebiegu procesu karnego (np. domniemanie niewinności, reguły dowodzenia, zakazy dowodowe itp.). Sprawia to, że przede wszystkim pokrzywdzony, ale także inni członkowie społeczeństwa oceniają wyrok, który zapadł, jako niesprawiedliwy (zwykle nadmiernie łagodny). Rzetelne uzasadnienie wyroku może pomóc uniknąć takich sytuacji. 
Oczywiście pokrzywdzony, który jest emocjonalnie zaangażowany w sprawę, nie musi się zgodzić z argumentacją sądu. Ma jednak możliwość zapoznania się z nią i być może, kiedy opadną emocje, zaakceptuje wyrok na poziomie racjonalnym. $\mathrm{Z}$ pewnością brak pełnego, wnikliwego uzasadnienia sądu może stwarzać pozór małej dbałości o poprawność rozstrzygnięcia, podważając tym samym zaufanie do sądu jako organu wymiaru sprawiedliwości, a przez to stawiając pod znakiem zapytania powinność stosowania się do obowiązujących norm prawa.

Glosowany wyrok Sądu Apelacyjnego w Białymstoku budzi ambiwalentne uczucia. $Z$ jednej strony zasługuje na aprobatę, ponieważ zarówno sama teza dotycząca strony podmiotowej, jak i jej uzasadnienie (in abstracto) stanowią rzadkość w praktyce orzeczniczej. Jednak przeniesienie tych rozważań dogmatycznych na grunt konkretnej sprawy pozostawia wiele do życzenia. Sąd apelacyjny, acz słusznie krytykuje tendencje do nadmiernego koncentrowania się na okolicznościach zewnętrznych, wydaje się nie mieć racji, negując zasadność wskazywanej przez prokuratora konieczności uwzględnienia także zachowania oskarżonych przy ocenie stronie podmiotowej.

Uświadomienie możliwości spowodowania śmierci nie przesądza samo w sobie ani o rodzaju zamiaru, ani nawet samej umyślności ${ }^{1}$. W doktrynie wyróżnia się dwa czynniki składające się na umyślność i nieumyślność, pozwalające rozróżnić poszczególne ich postacie. Jednym z nich jest świadomość, czyli czynnik poznawczy, zaś drugi to element wolicjonalny, pokazujący postawę sprawcy wobec możliwości popełnienia czynu zabronionego. Ustalenie, że sprawca miał świadomość na przykład możliwości spowodowania skutku w postaci śmierci człowieka, pozwala jedynie na wyeliminowanie jednego kształtu strony podmiotowej - niedbalstwa. Jak słusznie zauważył sąd apelacyjny, nie przesądza to jednak jeszcze o przyjęciu umyślności. Niezbędne jest zbadanie elementu wolicjonalnego, z czego często orzekające sądy zdają się rezygnować, przypisując sprawcy (zwykle na podstawie spowodowanego skutku) określony stosunek psychiczny do czynu. Dokładne ustalenie owego elementu wolicjonalnego nie jest proste, ponieważ jak wskazał sąd apelacyjny - konieczne jest tu zrekonstruowanie procesu motywacyjnego sprawcy, oparte na analizie jego osobowości, cech charakteru, poziomu intelektualnego, reakcji emocjonalnych, stosunku do otoczenia i zachowania się w różnych sytuacjach życiowych, a także tła i powodów zajścia, stosunku do pokrzywdzonego, zachowania przed i po czynie.

Na szczególną uwagę w omawianej sprawie zasługuje odtworzenie procesu motywacyjnego sprawców. Wywód w tej mierze jest spójny, logiczny, zaś wniosek o braku zamiaru bezpośredniego zabójstwa u sprawców wydaje się trafny.

Jakkolwiek godna pochwały jest staranność sądu apelacyjnego zmierzającego do uniknięcia pułapki przypisania strony podmiotowej sprawcy jedynie na podsta-

\footnotetext{
${ }^{1}$ Por. J. Giezek, Świadomość sprawcy czynu zabronionego, Warszawa 2013, s. 187 i n.
} 
wie okoliczności o charakterze przedmiotowym, zwłaszcza skutku, wydaje się, że sąd popadł w pewną przesadę i nie uwzględnił ich w ogóle. Ustalenie kształtu elementu wolicjonalnego jest trudne, zwłaszcza na „styku” godzenia się i chęci uniknięcia skutku. W niniejszej sprawie sąd bezsprzecznie wykazał jedynie, iż sprawcy przed popełnieniem czynu nie mieli zamiaru bezpośredniego zabójstwa. Zarówno zwyczaje obowiązujące $\mathrm{w}$ ich kręgu społecznym, jak i wiodący motyw ich zachowania (chęć ukarania pokrzywdzonego za donoszenie) wskazują na jego brak. Paradoksalnie, najwyraźniej świadczy o tym ostatni fragment czynu jednego ze sprawców, który dokonał zgwałcenia analnego pokrzywdzonego. Było to zachowanie o charakterze symbolicznym, mające na celu napiętnowanie pokrzywdzonego. Bardzo przykre konsekwencje dla pokrzywdzonego związane z byciem ofiarą takiego czynu są możliwe tylko wówczas, gdy ten żyje. To wszystko pokazuje jedynie, że sprawcy nie chcieli śmierci pokrzywdzonego i nie dążyli do jej spowodowania. Nie przesądza to jednak o tym, czy sprawcy godzili się na skutek w postaci śmierci, czy sądzili, iż uda im się go uniknąć.

Trudno się zgodzić z argumentacją sądu apelacyjnego odnośnie do wnioskowania o zamiarze na podstawie użytego narzędzia oraz sposobu działania sprawców. Sąd stwierdził, że wbrew sugestiom prokuratora ani liczba zadanych uderzeń, ani narzędzie, którym zostały zadane, nie świadczą jednoznaczne o zamiarze zabójstwa. Niezależnie od istniejących rozbieżności dotyczących liczby zadanych ciosów (kilkanaście zdaniem prokuratora, kilka zdaniem sądu) nie ulega wątpliwości ich lokalizacja. Były one zadawane w głowę, czyli miejsce, jak się podkreśla i w orzecznictwie, i w doktrynie, szczególnie newralgiczne dla życia i zdrowia człowieka.

Na marginesie warto zauważyć, iż sąd skupił się na dokładnym rozliczeniu liczby ciosów (zwłaszcza zadanych szafką), a nie uwzględnił ich całokształtu. Jeśli nawet ciosów zadanych szafką było tylko kilka (3-4), to zważywszy na to, że kilkanaście innych było efektem uderzeń „tylko” pięścią, nie zmienia to faktu, iż całe zdarzenie było wysoce niebezpieczne dla zdrowia i życia pokrzywdzonego. Nie można zupełnie zgodzić się z wywodem sądu apelacyjnego dotyczącego sposobu posłużenia się szafką przez sprawców. W uzasadnieniu bowiem czytamy:

[...] zdaniem biegłego [pokrzywdzony] był bity tą szafką, kiedy znajdował się w pozycji leżącej, przez co sprawca nie miał możliwości nadania temu narzędziu dostatecznie dużej siły. Prawdopodobnie uderzając szafką, trącał o podłogę, przez co ciosy wyhamowywały, a sprawca nie mógł się dostatecznie zamachnąć, nie miał dostatecznie dużej siły, aby rozbić szafkę, bądź połamać podstawę lub sklepienie czaszki. Jednocześnie opiniujący nie był w stanie kategorycznie stwierdzić, które obrażenia spowodowały śmierć pokrzywdzonego, będącą efektem nałożenia się kilku przyczyn, tj. niewydolności oddechowej i krążeniowej powstałej w następstwie urazu czaszkowo-mózgowego.

Z dostępnego materiału nie wynika, jaką szafką posłużyli się sprawcy. Należy domyślać się, że nie była zbyt duża, ponieważ sprawca swobodnie ją podnosił, ale 
i niezbyt mała, prawdopodobnie użyto by wówczas innego słowa, np. „,szafeczka” lub określenia „mała szafka”; mały rozmiar szafki zostałby zapewne użyty jako dodatkowy argument przemawiający przeciwko przyjęciu zamiaru zabójstwa. Na podstawie opisu spowodowanych obrażeń należy wnosić, iż była ona wykonana $\mathrm{z}$ twardego materiału (może drewna, sklejki lub plastiku), raczej nie z metalu, gdyż fakt ten zostałby zapewne użyty jako argument przemawiający za przyjęciem zamiaru zabójstwa.

Przy zadaniu nawet „tylko” trzech uderzeń szafką w głowę człowieka trudno racjonalnie przyjąć, iż zadający je człowiek, nawet w stanie upojenia alkoholowego, nie zdaje sobie sprawy z możliwości spowodowania bardzo poważnych obrażeń czy nawet śmierci. Jeżeli kontynuuje takie zachowanie, to znaczy, że w istocie jest mu obojętne, jak bardzo skrzywdzi ofiarę. Na tym polega natura zamiaru ewentualnego - sprawca nie dąży to osiągnięcia jakiegoś skutku, ale przewiduje możliwość jego nastąpienia i jest mu to obojętne. W niniejszej sprawie trudno znaleźć okoliczności świadczące o tym, że sprawcy próbowali w jakiś sposób uniknąć nastąpienia skutku w postaci śmierci pokrzywdzonego. Nie można zgodzić się z sądem apelacyjnym, który stwierdził:

[...] gdyby oskarżeni mieli zamiar zabójstwa, nie ograniczyliby się do bicia pięściami i kilkukrotnego uderzenia szafką, ale bez najmniejszych przeszkód zrealizowaliby go, używając np. pozostającego w zasięgu ręki noża (zdarzenie rozgrywało się w pobliżu kuchni), czy stosując skuteczniejszą metodę, np. duszenie, którego ślady stwierdzono na szyi denata [...]. Przeżyciowość obrażeń wskazująca jednak na umiarkowane użycie siły, zadawanie uderzeń pięścią i kilkakrotnie szafką, którą trudno uznać za typowe narzędzie śmiercionośne, pomimo wielości ciosów (około dwudziestu) i skoncentrowania ich w obrębie głowy, także przy towarzyszącej świadomości spowodowania najdalej idącego skutku, nie oznacza jeszcze chcenia czy akceptacji jego zaistnienia.

Wywód jest pełen sprzeczności i nie wynika z niego bynajmniej brak zamiaru zabójstwa u sprawców. Dałoby się go zaakceptować, gdyby sąd doprecyzował, że chodzi o zamiar bezpośredni. Niezupełnie zrozumiała jest linia rozumowania sądu apelacyjnego odnośnie do szafki - jako typowo nieśmiercionośnego narzędzia. To, że mebel nie jest przeznaczony do zadawania śmierci, nie znaczy, że nie może zostać w ten sposób wykorzystany i że jego użycie nie może doprowadzić do takiego skutku.

Sąd wywodził również, iż zachowanie sprawców (po dokonanym czynie) polegające na braku podjęcia próby udzielenia pomocy pokrzywdzonemu i zajęciu się usuwaniem śladów zdarzenia, nie świadczy o godzeniu się na skutek w postaci śmierci pokrzywdzonego. Zdaniem sądu:

Niewykazanie troski o los pokrzywdzonego to niekoniecznie przejaw godzenia się na jego śmierć, ale równie dobrze jedynie akceptacja skutku w postaci ciężkiego uszczerbku na zdrowiu. Nie można przy tym zapominać, że świadkiem zdarzenia był A. K., mogli więc liczyć na jego inter- 
wencję. Czyszczenie ubrań i pozbywanie się użytych przedmiotów to oczywiście próba zacierania śladów, ale taka motywacja przyświeca nie tylko sprawcom zabójstwa, ale także każdego innego przestępstwa i nie stanowi kryterium prawidłowej kwalifikacji prawnej czynu. Przy czym znamienne jest, że starali się ukryć np. kij od szczotki, pozostawiając szafkę na pokrzywdzonym, co również sugeruje, że nie przypuszczali, iż J. Ż. nie żyje, a ich zachowanie wynikało z lekceważenia spowodowanych obrażeń, których skutkiem byli zaskoczeni.

W zacytowanym fragmencie sąd kilkakrotnie wskazał, że sprawcy wykazali obojętność wobec stanu pokrzywdzonego (spowodowanych obrażeń) ${ }^{2}$. Już w pierwszym zdaniu sąd zwrócił uwagę na brak troski, czyli zainteresowania jego stanem. Faktycznie nie tylko zabójcy starają się zatrzeć ślady popełnionego przez siebie czynu, ale nie sposób podzielić pogląd sądu apelacyjnego, że w tej sprawie zachowanie sprawców po czynie nie stanowi przesłanki przyjęcia zamiaru ewentualnego zabójstwa. Sąd źle położył tu akcent - nie chodzi o to, że sprawcy zacierali ślady, czy czego ślady zacierali; rzecz w tym, że okazali w ten sposób całkowity brak zainteresowania losem pokrzywdzonego. Nie ma w dostępnym materiale żadnych informacji na temat tego, by zanim zajęli się zacieraniem śladów, sprawdzili chociażby, czy pokrzywdzony oddycha. Nie można zinterpretować ich zachowania, odmiennie od tego, co twierdzi sąd, inaczej niż jako obojętność wobec spowodowanego skutku. Sugestia sądu, że mogli sądzić, iż obecny świadek zdarzenia może udzielić pokrzywdzonemu pomocy, jest zdaje się wyłącznie przypuszczeniem sądu. Nawet gdyby jednak przyjąć, iż oskarżeni tak pomyśleli, to również nie wskazuje na to ich zaangażowanie w uniknięcie skutku. Idąc tropem rozumowania sądu, można powiedzieć, że gdyby oskarżonym faktycznie zależało na losie pokrzywdzonego, wystarczyło, iż nie przerywając sprzątania, zleciliby świadkowi sprawdzenie jego stanu.

Wbrew zatem stwierdzeniu sądu apelacyjnego, w analizowanej sprawie istnieje wiele okoliczności o charakterze przedmiotowym, które uwzględnione łącznie z okolicznościami o charakterze podmiotowym pozwalają na przypisanie oskarżonym zamiaru ewentualnego zabójstwa.

Zastanawiająca jest kwalifikacja prawna fragmentu czynu, polegającego na rozebraniu pokrzywdzonego i włożeniu mu do odbytu kija od szczotki, czy raczej jej brak. Takie zachowanie nie mieści się w znamionach ani pobicia, ani zabójstwa, czy też spowodowania uszczerbku na zdrowiu. Włożenie kija do odbytu człowieka stanowi niewątpliwie czynność seksualną. W doktrynie pojawiają się rozbieżności odnośnie do tego, czy jest to surogat obcowania płciowego, czy inna czynność seksualna ${ }^{3}$. Autorka niniejszej glosy opowiada się za pierwszym stano-

${ }^{2} \mathrm{Na}$ „obojętność woli” jako element konstytutywny zamiaru ewentualnego wskazywał W. Wolter, Nauka o przestępstwie, Warszawa 1973, s. 127.

${ }^{3}$ Por. literatura powołana: M. Budyn-Kulik, M. Kulik [w:] M. Królikowski, W. Zawłocki (red.), Kodeks karny. Część szczególna, t. 1, Warszawa 2013, s. 611-612. 
wiskiem. Nie ulega także wątpliwości, iż dopuszczenie się obcowania płciowego bez zgody pokrzywdzonego nie musi wypływać z motywacji seksualnej, nie musi prowadzić do zaspokojenia popędu płciowego sprawcy, pomimo pojawiających się niekiedy wypowiedzi prezentujących pogląd odmienny ${ }^{4}$.

W analizowanej sprawie pewne wątpliwości można mieć jedynie co do tego, czy można uznać, iż sprawca doprowadził pokrzywdzonego przemocą do obcowania płciowego. Materiał z akt sprawy jest skąpy, dostępny jedynie pośrednio poprzez uzasadnienie sądu apelacyjnego, wyrok sądu I instancji nie był kwestionowany w tej mierze, trudno zatem dokonać tu jakichś wiążących ustaleń. Możliwa jest sytuacja, że sprawca, który powodowany był chęcią ukarania pokrzywdzonego, od początku zdarzenia miał zamiar włączenia do owego ukarania także takiego elementu. Wyrządzenie krzywdy w postaci spowodowania bolesnych, poważnych obrażeń ciała, byłoby wówczas jedynie dodatkową „korzyścią” (w postaci wyżycia się, rozładowania agresji, uzyskania satysfakcji) dla sprawców oraz stanowiło niejako przygotowanie pokrzywdzonego do wymierzenia mu kary właściwej poprzez uniemożliwienie mu stawienia skutecznego oporu. Wówczas nie ma przeszkód do przyjęcia, że przynajmniej jeden ze sprawców - K. Ł. popełnił również zgwałcenie, które w tych warunkach należy uznać za popełnione ze szczególnym okrucieństwem. Jeżeli drugi ze sprawców również obejmował zamiarem ten fragment czynu, niezależnie od tego, jaka była jego faktyczna rola $\mathrm{w}$ jego popełnieniu (nie jest to jasne na podstawie dostępnych danych), powinien odpowiadać jako współsprawca, co sprawia, że zgwałcenie owo powinno jednocześnie zostać uznane za zgwałcenie zbiorowe.

Kwalifikacja czynu przypisanego każdemu ze sprawców wyglądałaby wówczas następująco: art. 148 § 2 pkt 2 w zb. z art. 197 § 3 i 4 k.k. w zw. z art. 197 $\S 1$ k.k. Jeżeli sprawca (jeden - K. Ł.) dopiero w trakcie czynu, widząc, że pokrzywdzony leży i nie porusza się, czując się na przykład nieusatysfakcjonowany dotychczas zadanym cierpieniem, wpadł na pomysł dalszego jego ukarania, jego zachowanie należy potraktować jako eksces współsprawcy. Wówczas za zachowanie polegające na wykonaniu czynności seksualnej odpowie tylko ten sprawca, który się go dopuścił. Nasuwa się jednak pytanie, czy w takiej sytuacji doprowadził on pokrzywdzonego przemocą do obcowania płciowego, czy wykorzystał jego bezradność. W doktrynie nie analizuje się takiej sytuacji, a jedynie taką, w której sprawca obcuje płciowo z osobą, która została doprowadzona przez inną osobę do stanu bezradności. Przyjmuje się wówczas, że czyn sprawcy wypełnia znamiona przestępstwa $\mathrm{z}$ art. 198 k.k. ${ }^{5}$

${ }^{4}$ Tzw. zamiar lubieżny przyjmował np. M. Filar, Przestępstwo zgwatcenia $w$ polskim prawie karnym, Toruń 1974; M. Rodzynkiewicz [w:] A. Zoll (red.), Kodeks karny. Komentarz. Czesść szczególna, t. II, Kraków 2006, s. 528-529.

${ }^{5}$ M. Mozgawa [w:] M. Mozgawa (red.) Kodeks karny. Komentarz, Warszawa 2013, s. 463; M. Budyn- Kulik, M. Kulik [w:] M. Królikowski, W. Zawłocki (red.), op. cit., s. 629. 
Jeżeli ten sam sprawca najpierw stosuje przemoc (ale nie instrumentalnie, tylko dla samej przemocy), a potem dopuszcza się obcowania płciowego z pokrzywdzonym, spawa się komplikuje. Można tu chyba bronić obu poglądów: że jego czyn wypełnia znamiona typu z art. 197 k.k. oraz z art. 198 k.k. Autorce niniejszej glosy bliższa jest pierwsza interpretacja ${ }^{6}$. Do znamion czynu zabronionego z art. 197 k.k. nie należy przemoc instrumentalna - doprowadzająca do obcowania płciowego. Jeżeli zatem sprawca jednym czynem - rozciągniętym w czasie, składającym się z kilku fragmentów, ale tworzącym zwartą całość pod względem miejsca, czasu, innych okoliczności, uczestników zdarzenia etc. ${ }^{7}$ - najpierw stosuje przemoc bez zamiaru przełamania oporu dotyczącego poddania się czynności seksualnej pokrzywdzonego, a w trakcie czynu podejmuje także zamiar obcowania płciowego z pokrzywdzonym, należy uznać jego czyn za wypełniający znamiona typu z art. 197 k.k. odnośnie do oskarżonego K. Ł. W takim przypadku kwalifikacja pozostałaby taka sama jak zaproponowana wyżej, natomiast w stosunku do drugiego z oskarżonych zniknąłby z niej art. 197 k.k.

Teza postawiona przez sąd apelacyjny zasługuje na aprobatę. Niestety, choć z dogmatycznego punktu widzenia jest poprawna, co więcej, pozytywnie odbiega od obserwowanej praktyki orzeczniczej, nie przystaje do stanu faktycznego stanowiącego podstawę glosowanego orzeczenia. Strona podmiotowa, a w szczególności zamiar ewentualny, ciągle w praktyce rodzi problemy. Nie można oprzeć się wrażeniu, że po fali krytyki spowodowanej bardzo pochopnym przypisywaniem przez sądy zamiaru ewentualnego, obecnie traktowany jest on bardzo ostrożnie. Zamiar ewentualny jest „pełnoprawną” postacią umyślności wprost wskazaną przez ustawodawcę w art. $9 \S 1$ k.k. Nie chodzi zatem o to, aby unikać przypisywania zamiaru ewentualnego wówczas, gdy istnieją przesłanki do tego, lecz aby nie przypisywać go wyłącznie dlatego, że nie można dowieść zamiaru bezpośredniego. Problem polega bowiem na tym, że sądy „zakładały” umyślność i w braku dowodów na zamiar bezpośredni, przyjmowały ewentualny. Zamiar ewentualny ma własne przesłanki, których istnienie sąd powinien wskazać w uzasadnieniu. Ustalenie strony podmiotowej jest szczególnie trudne, chociaż niezasadna jest obawa sądów, iż dokładne jej ustalenie i opisanie wiązać się musi z pogłębioną analizą psychologiczną, do czego być może nie czują się kompetentne. Często jest to jedynie kwestia wyprowadzenia racjonalnych i logicznych wniosków ze zgromadzonego materiału dowodowego.

${ }^{6} \mathrm{~W}$ tym kierunku zdaje się iść J. Warylewski [w:] A. Wąsek, R. Zawłocki (red.), Kodeks karny. Część szczególna, t. 1, Warszawa 2010, s. 1026-1027.

${ }^{7}$ A. Wąsek [w:] O. Górniok, S. Hoc, M. Kalitowski, S. M. Przyjemski, Z. Sienkiewicz, J. Szumski, L. Tyszkiewicz, A. Wąsek, Kodeks karny. Komentarz, Gdańsk 2005, s. 156-158; M. Cieślak, Polskie prawo karne. Zarys systemowego ujęcia, Warszawa 1994, s. 152-154. 